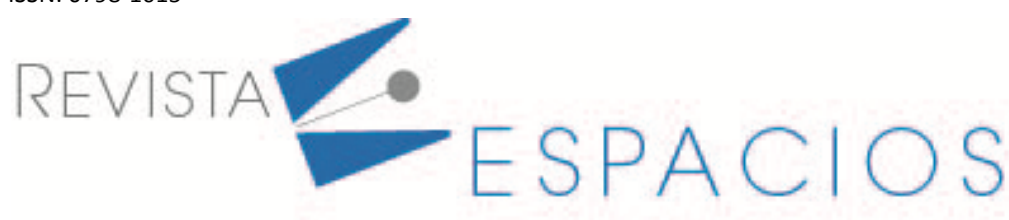

Vol. 41 (49) 2020 • Art. 4

\title{
Quantitative analysis of intrafamily religious violence in the Bogotá city (Colombia)
}

\section{Análisis cuantitativo de la violencia religiosa intrafamiliar en la ciudad de Bogotá, Colombia}

\author{
RENDÓN M., Alba L. ${ }^{1}$ \\ RODRÍGUEZ M., Juan P. ${ }^{2}$ \\ SÁNCHEZ C., Juan M. ${ }^{3}$
}

\begin{abstract}
This paper aims to analyze the existence of acts of domestic violence in the city of Bogotá, Colombia, during the period between 2014 to 2018, when one or more members profess a different religion to which the other members of his family, belief, custom or manifest not believing in anything; how this type of violence due to religion is related to other types of violence and the consequent need to identify, prevent, protect and punish victims, by the competent authorities, to ensure the fundamental right to religious freedom, in harmony with human rights treaties and conventions ratified by Colombia, the Public Policy of religious freedom and Jurisprudence pronouncements. It was applied a survey to 350 people whose results were subject to multiple correspondence analysis, descriptive analysis and some hypothesis testing were performed. It was found that both men and women who have suffered religious violence within their family nucleus, in their majority do not denounce because the lack of identity that the fundamental right to religious freedom has in the country is still incipient and lacks statistics that allow the development of public policies according to reality, that permit guaranteeing this fundamental right in Colombia.
\end{abstract}

key words: religious violence, domestic violence, Bogotá, Multiple Correspondence Analysis.

\begin{abstract}
Resumen
Este artículo tiene como objetivo analizar la existencia de hechos de violencia intrafamiliar en la ciudad de Bogotá, Colombia, durante el período comprendido entre 2014 y 2018, cuando uno o más miembros profesan una religión diferente a la que los demás miembros de su familia; y cómo este tipo de violencia de origen religioso se relaciona con otros tipos de violencia y la consecuente necesidad de identificar, prevenir, proteger y sancionar a las víctimas, por parte de las autoridades competentes, para garantizar el derecho fundamental a la libertad religiosa, en armonía con los tratados de derechos humanos y convenios ratificados por Colombia, la Política Pública de libertad religiosa y pronunciamientos de Jurisprudencia. Se aplicó una encuesta a 350 personas cuyos resultados fueron sometidos a análisis de correspondencia múltiple, análisis descriptivo y se realizaron algunas pruebas de hipótesis. Se encontró que tanto hombres como mujeres que han sufrido violencia religiosa dentro de su núcleo familiar, en su mayoría no denuncian porque la falta de identidad que tiene el derecho fundamental a la libertad religiosa en el país aún es incipiente y carece de estadísticas que permitan el desarrollo de políticas públicas acordes a la realidad, que permitan garantizar este derecho fundamental en Colombia.
\end{abstract}

\footnotetext{
${ }^{1}$ Abogada. Maestría en Derecho de Familia. Facultad de Derecho. Universidad Antonio Nariño (Bogotá, Colombia). Correo electrónico: arendon03@uan.edu.co,albaluciarm29@hotmail.com

2 Profesor Titular. Facultad del Medio Ambiente y Recursos Naturales. Universidad Distrital Francisco José de Caldas. Correo electrónico: jprodriguezm@udistrital.edu.co

${ }_{3}^{3}$ Profesor Asociado. Facultad de Ingeniería. Universidad Distrital Francisco José de Caldas. Correo electrónico: jmsanchezc@udistrital.edu.co
} 
Palabras clave: violencia religiosa, violencia intrafamiliar, Bogotá, Análisis de Correspondencia

Múltiple.

\section{Introduction}

Colombia before the 1991 constitution, was considered a Catholic nation, so keeping one in close relationship with the Catholic Church institution. But from the 1991 Constitution, the country is established as a secular nation in which Colombian citizens have worship freedom. This is established in article 19 of the 1991 constitution, which states:

"Freedom of worship is guaranteed. Everyone has the right to freely profess their religion and to spread it individually or collectively. All religious denominations and churches are equally free before the law" (Constitición de Colombia, 1991).

This internationally recognized right is regulated and supervised by the United Nations Organization "ONU" and at the regional level by the Inter-American Human Rights System of the American States Organization "OEA". But although religious freedom is a fundamental right that is to enshrined in the Colombian Constitution, in some cases it appears that people who profess different religions to the family in Colombia is typically Catholic, have some kind of discrimination or violence on the part of other relatives when professing different religions. Citizens who profess the Catholic religion for the 2016 corresponding to $73 \%$ of the population in Colombia, of which $17.7 \%$ of this population are found living in Bogotá (Observatorio de la Democracia, 2017). Globally, few studies have been conducted in this regard, can be named Carter in 2017, which was carried out in the United Kingdom within Muslim communities (Carter, 2017); and Hutchinson's in the United States (Hutchinson, 2013).

Therefore, this article intends to carry out an analysis on violence for religious freedom in the Bogotá city, Colombia, within family nuclei, also seeking to distinguish if there is a difference, due to being a man or a woman, seen from a legal perspective. The following chapter introduces the related basic concepts. Then the applied methodology. In order to present the results and finally the conclusions.

\section{Legal scope in colombia}

For a better understanding of the concept of religious freedom within the family, protection of the family, domestic violence and types of violence are three concepts presenting in this chapter.

2.1. Protection of the family. In accordance with the ruling of Constitutional Court T-292 of two (2) June 2016, with the Speaker Judge, the family institution was defined as a right like this:

"The constituent regulated the family institution as a right and essential nucleus of society in Article 42 Superior. In accordance with this provision, the family "is constituted by natural or legal ties, by the free decision of a man and a woman to contract marriage or by the responsible will to conform it."

"The family is a sociological institution derived from the nature of the human being," the entire community benefits from its virtues as well as is harmed by the conflicts that arise from it. "Among its essential purposes are common life, mutual aid, procreation, support and education of children. Consequently, both the State and society must strive for their well-being and ensure their integrity, survival and conservation. Guidelines that permeated its political and legal recognition in the 1991 Constitution" (Mendoza Martelo, 2016). 
"Without intending to exhaust the constitutional provisions that protect its protection, it is emphasized that article 5 provides that the State must protect the family as the basic institution of society; next, article 13 states that no one can be discriminated against on the basis of family origin; Article 15 regulates the right to family privacy.

In Colombia equality is preached in the protection of the different forms of family composition, in fact, since the construction of the Constitution of 1991 it was determined that "such protection would not be exhausted in a certain type of family structured from ties protected in certain religious and/or legal solemnities, but would also extend to those relationships that, regardless of the nature or source of the bond, fulfill the basic functions of the family." (Congreso de Colombia, 2000).

2.2. Family violence concept. Considering that the violence generated in the family triggers more violence, the legislator decided, in development of article 42 of the Constitution, to specifically sanction this behavior and for this purpose issued Law 294 of 1996, which in article 22 of the chapter on crimes against harmony and family unity, established domestic violence as a crime, in the following terms:

"Article 22. Intra-family violence. Anyone who physically, psychically or sexually abuses any member of their family nucleus, shall be imprisoned for one (1) to two (2) years." (Congreso de Colombia, 2008)

The Constitutional Court in judgment C-674 of 2005, with the reporting Rodrigo Escobar Gil magistrate establishes that, by intra-family violence it can be understood:

"All damage or physical mistreatment, mental, cruel abuse, intimidating or demeaning, threatening, tort, offense or any other form of aggression against the natural way to proceed with momentum and extraordinary intensity, produced among people so permanently they are integrated into the domestic unit, although they do not live under the same roof. Conduct that to be penalized according to the defendant article, requires that violence whatever the mechanism to inflict it, be unlawful because it results in the affectation and destabilization of family unity and harmony" (Cepeda Espinoza, 2005).

Law 1257 of 2008, in Chapter V - Protection measures, has indicated in article 16 the following: Article 16. Article $4{ }^{0}$ of Law 294 of 1996, modified by article $1^{0}$ of Law 575 of 2000, it will look like this:

"Article $4{ }^{0}$ Any person who, within their family context, is the victim of physical or psychological damage or damage to their sexual integrity, threat, tort, offense or any other form of aggression by another member of the family group, may request, without prejudice to any criminal complaints, to the family commissioner of the place where the events occurred and in the absence of this to the Municipal Civil Judge or Municipal Promiscuo, an immediate protection measure that ends violence, mistreatment or aggression or avoids that this be done when it is imminent" (Congreso de Colombia, 2008).

2.3. Types of violence. Violence in Colombia is typified by two factors: the way in which violence is exercised and the subject or subjects that exercise it. These two factors are the ones that structure the classification of the types of violence:

- Psychological violence. "Emotional or psychological abuse occurs in those situations in which the significant people on whom the dependent depends, disqualify, humiliate, discriminate, ignore his 
feelings, submit his will or subordinate him in different aspects of his existence that affect his dignity, self-esteem and mental and moral integrity" (Arévalo Barea, 2016).

- Physical violence. It is the easiest violence to identify, because its consequences are clearly visible visually. This consists in carrying out a physics aggression to the body and the victim looking to hurt, causing pain to the person and sometimes death (Martínez Pacheco, 2016).

- Verbal violence. This is where the offender intends to harm psychologically the aggressor through of a speech, which is hurtful and seeks to destroy their self - esteem and sometimes their image being the other (Herrera Rodas, Peraza Segura, \& Porter Aguilar, 2004)

- Sexual violence. This seeks to denigrate a person through the appeal of its sexual dimension and the perpetrator seeks satisfaction sexual (Biblioteca del Congreso Nacional de Chile, 2015). This may have additionally the component of physical and psychological violence.

- Economic violence. It is a type of violence in which the ability of one or more people to use money is damaged. It is also in which the aggressor uses his economic power to control the decisions of the attacked (Sánchez Lara, 2017).

- Negligence. And it the aggression is the omission of action necessary to address the development and well - being physical and psychological another (Soriano Faura, 2015).

It can be said that religious violence domestic, is presented within a group of people belonging to a domestic unit, but do not live in the same house. In which one of the members of the unit carries out some type of aggression or violence on another member of the unit, motivated by the fact that the attacked person professes his religious beliefs different from that of the aggressor.

\section{Metodology}

The applied methodology is descriptive with a quantitative approach. In Figure 1, you can see the applied method.

The techniques and tools used during the investigation are presented below:

- The surveys that were carried out were applied by virtual means, individual, email.

- The type of sampling was non-probabilistic for convenience, so the results obtained cannot be generalized for the entire population of Bogotá.

- The statistical tests were done through the R software. The R software is a free software environment for statistical computing and graphics. This software is supported by the R Foundation for Statistical Computing.

- Correspondence analysis (CA) is a multivariate statistical technique. It is similar to principal components analysis, but it applies to categorical data rather than continuous. It presents a data set in twodimensional graphical form. Contingency tables are used for the correspondence analysis (CA). This technique decomposes the chi-square statistic associated with this table into orthogonal factors.

- the $z$ test was used to reject or not the null hypothesis. 
Figure 1

Applied method

Define the objectives of the Research

Define the information needed

Determine the content of the questions

Write the questions and build the questionnaire

Conduct Survey

Debug and encode information

Correspondence Analysis between variables

Apply Multiple Correspondence Analysis (ACM)

Descriptive Analysis

Inferential Analysis

Analyze Results

Obtain Conclusions

Source: Autors

\section{Results}

The results were obtained by dividing it into two groups, men and women. The results are presented.

4.1. Group women. The first analysis is a correspondence analysis between variables, which seeks to determine between which questions there is a correspondence within the population of women. The result is observed in Figure 2.

Figure 2

Result Correspondence Analysis of questions within the group of women.

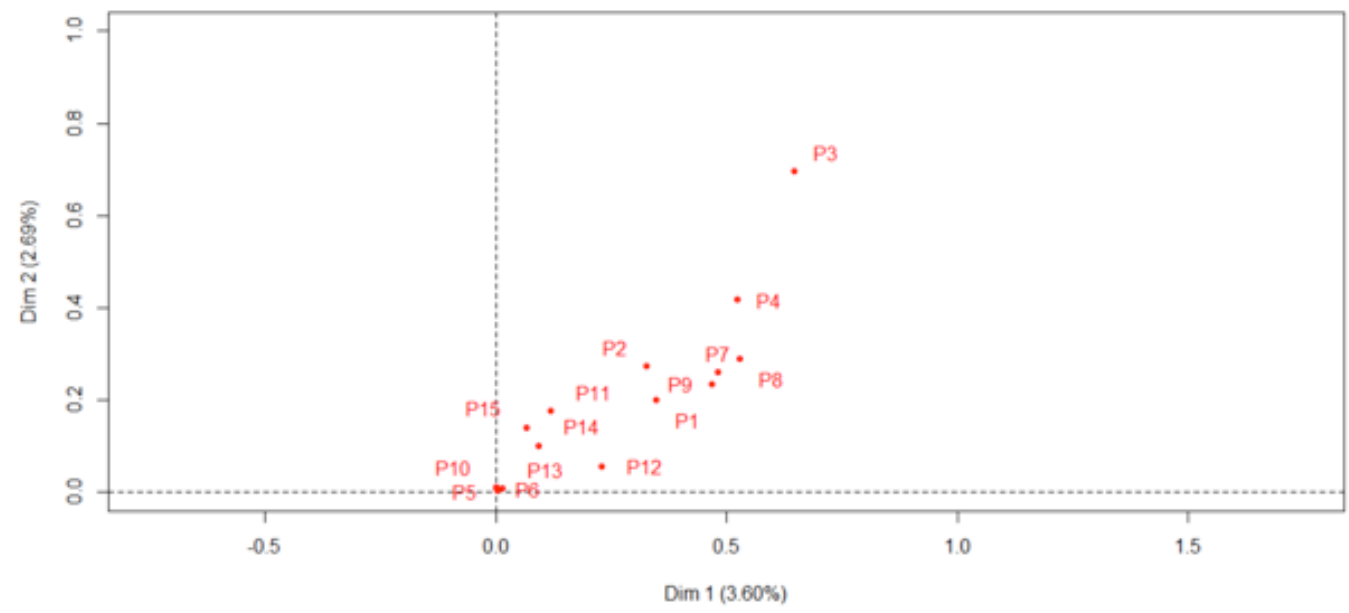

Source: Software R., Adapted Autors 
From the results, the questions were determined grouped as follows:

- $\quad$ Group 1 (P4, P7, P8, P9)

- $\quad$ Group 2 (P1, P2, P11)

- $\quad$ Group 3 (P14, P15)

- $\quad$ Group 4 (P5, P6, P10, P13)

Group 1 Analysis (P4, P7, P8, P9). Table 1 shows the questions and their respective categories.

Table 1

Questions Group 1 Women

\begin{tabular}{|c|c|}
\hline QUESTION & CATEGORÍES \\
\hline $\begin{array}{l}\text { P4. ¿ How often do you attend the place where you practice } \\
\text { your religion? }\end{array}$ & $\begin{array}{l}\text { Every day; } 1 \text { or } 2 \text { times a week; weekends; Once a } \\
\text { month; every six months; Once a year; on special } \\
\text { dates; never }\end{array}$ \\
\hline $\begin{array}{l}\text { P7. ¿ During the years } 2014 \text { to } 2018 \text {, you have been a victim } \\
\text { of violence due to the religion you practice, in your family? }\end{array}$ & Yes; No \\
\hline $\begin{array}{l}\text { P8. } ¿ \text { In case of having suffered intra-familiar violence by } \\
\text { different religion, cult or belief with his Family, the violence } \\
\text { has been: }\end{array}$ & $\begin{array}{l}\text { Verbal; physical; psychological; economic; I have not } \\
\text { suffered any type of violence. }\end{array}$ \\
\hline $\begin{array}{l}\text { P9. ¿ If you have been a victim of domestic violence } \\
\text { because of the religion you practice, you reported these } \\
\text { facts? }\end{array}$ & Yes; No; \\
\hline
\end{tabular}

Source: Autors

Figure 3 shows the result of correspondence analysis of Group 1 of women questions.

Figure 3

Result Correspondence Analysis

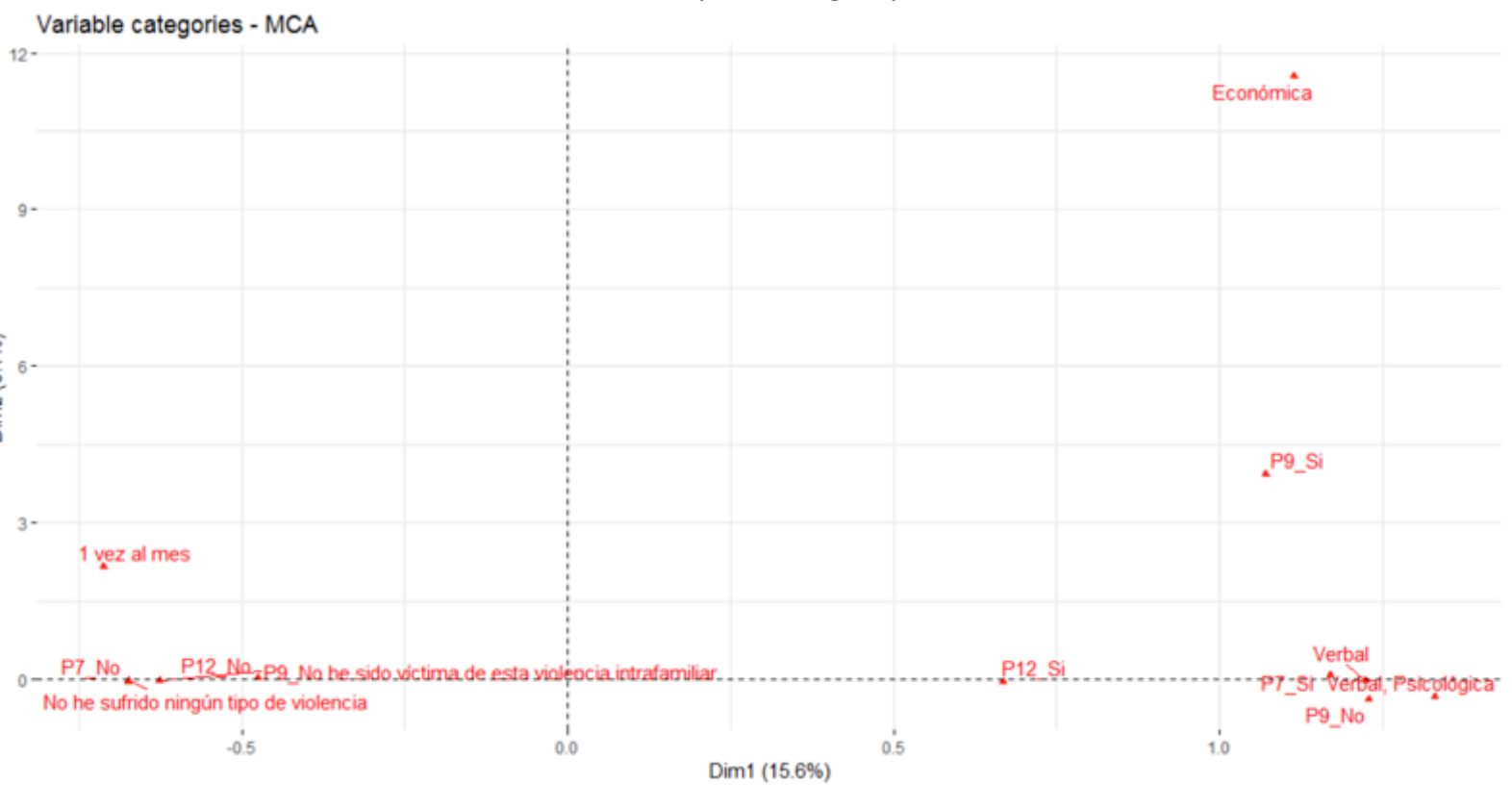

Source: Software R., Adapted Autors

Table 2 shows how the categories of group of questions 1 of women were grouped, with their respective analysis. 
Table 2

Categories grouping of women questions group 1

\begin{tabular}{|c|c|c|}
\hline Group & Question (Categorie) & Analysis \\
\hline \multirow[t]{4}{*}{1} & P4 (1 time a month) & \multirow{4}{*}{$\begin{array}{l}\text { There is a correlation between the group of women who go } \\
\text { once to their religious practice, and have not suffered any } \\
\text { type of religious violence, nor intra-family violence. }\end{array}$} \\
\hline & P7 (No) & \\
\hline & $\begin{array}{l}\text { P8 (I have not suffered any type of } \\
\text { violence) }\end{array}$ & \\
\hline & $\begin{array}{l}\text { P9 (I have not been a victim of this } \\
\text { domestic violence) }\end{array}$ & \\
\hline \multirow[t]{4}{*}{2} & P7 (Yes) & \multirow{4}{*}{$\begin{array}{l}\text { There is a correlation between the group of women who have } \\
\text { suffered violence because of their religion, who have suffered } \\
\text { verbal and psychological violence and did not report these } \\
\text { events. }\end{array}$} \\
\hline & P8 (Verbal) & \\
\hline & P8 ( Psychological) & \\
\hline & P9 (No) & \\
\hline
\end{tabular}

Source: Autors

In conclusion, there are two groups of women, the first have not suffered religious violence and the second that have suffered violence because of their religious practice and the type of violence they have suffered is verbal and psychological, and although they were victim of this type of violence, they did not report these events.

Group 2 Analysis (P1, P2, P11), Table 3 shows the questions and their respective categories.

Table 3

Questions Group 2 Women

\begin{tabular}{|c|c|}
\hline QUESTION & CATEGORIES \\
\hline $\begin{array}{c}\text { P1. Do you and your family belong to a certain religion or do you } \\
\text { practice different beliefs? }\end{array}$ & Yes; No \\
\hline $\begin{array}{c}\text { P2. Do you consider that religion contributes values in the family to } \\
\text { prevent domestic violence? }\end{array}$ & \\
\hline $\begin{array}{c}\text { P11. ¿ Before authority which would come to ask for a protective } \\
\text { measure to prevent further acts of domestic violence for violation of } \\
\text { the fundamental right to religious freedom against him? }\end{array}$ & $\begin{array}{c}\text { Family judge; family commissioner; family } \\
\text { well-being; prosecution; national police; legal } \\
\text { medicine; none; all }\end{array}$ \\
\hline
\end{tabular}

Source: Autors

Figure 4 shows the result of correspondence analysis of Group 2 of women questions. 
Figure 4

Result Correspondence Analysis

of women questions Group 2.

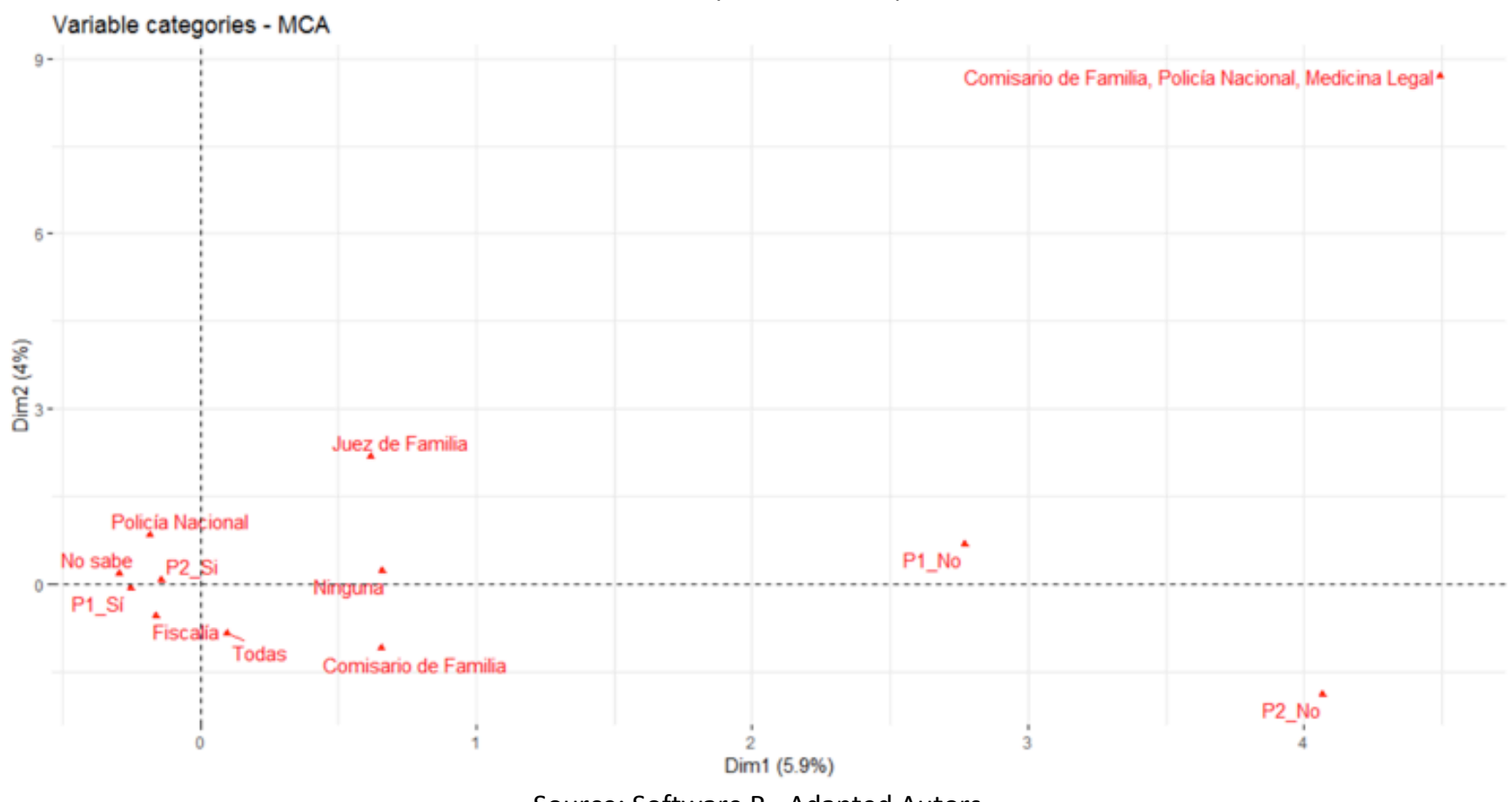

Source: Software R., Adapted Autors

Table 4 shows how the categories of group of questions 2 of women were grouped.

Table 4

Categories grouping of women questions group 2.

\begin{tabular}{|c|c|c|}
\hline Group & Question (Categorie) & Analysis \\
\hline \multirow[t]{5}{*}{1} & P1 (Yes) & \multirow{5}{*}{$\begin{array}{l}\text { There is a correlation between a group of women that practice any religion and } \\
\text { consider that religion contributes values in the family to prevent domestic violence, } \\
\text { and they know that they can report cases of religious violence to the police, the } \\
\text { prosecution or do not know. }\end{array}$} \\
\hline & P2 (Yes) & \\
\hline & P11 (Prosecution) & \\
\hline & P11 (Policy) & \\
\hline & P11 (Does not know) & \\
\hline \multirow[t]{2}{*}{2} & P1 (No) & \multirow{2}{*}{$\begin{array}{l}\text { There is a correlation between a group of women who do not practice any religion } \\
\text { and who do not consider that religion contributes values in the family to prevent } \\
\text { domestic violence. }\end{array}$} \\
\hline & P2 (No) & \\
\hline
\end{tabular}

Source: Autors

In summary, it is possible to group into two groups which are the women who practice a religion and consider that religion contributes values in the family to prevent domestic violence, and the other group of women who do not practice a religion and consider that religion does not contributes values in the family to prevent domestic violence due to this cause.

Group 3 Analysis (P14, P15), Table 5 shows the questions and their respective categories. 
Table 5

Questions

Group 3 Women

\begin{tabular}{|l|l|}
\hline QUESTION & CATEGORÍES \\
\hline $\begin{array}{l}\text { P14. Do you think it is important that the public policy of religious freedom and the public policy of } \\
\text { fundamental freedoms of religion and conscience be made known to the people of Bogotá? }\end{array}$ & Yes; No \\
\hline $\begin{array}{l}\text { P15. Do you agree with the advance of domestic violence prevention programs for religious violence } \\
\text { in your locality? }\end{array}$ & Yes; No \\
\hline
\end{tabular}

Source: Autors

Figure 5 shows the result of correspondence analysis of Group 3 of women questions

Figure 5

Result Correspondence Analysis

of women questions Group 3.

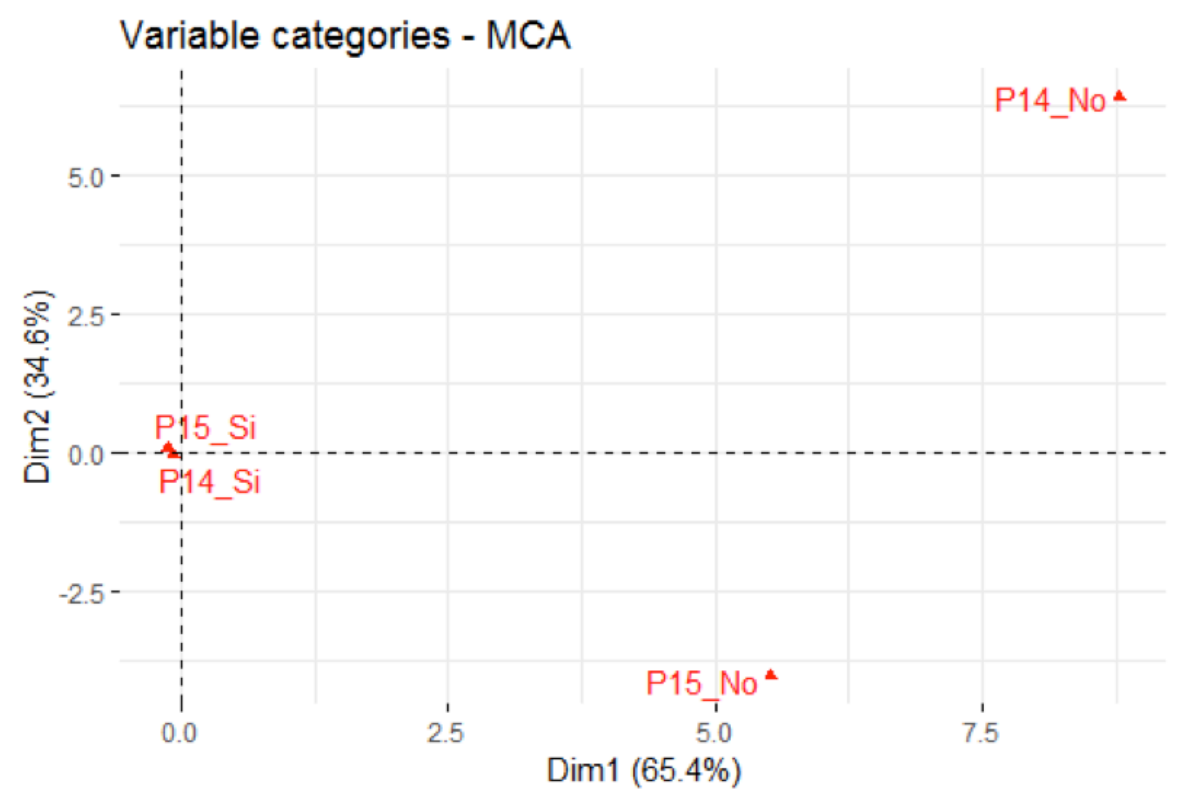

Source: Software R., Adapted Autors

Table 6 shows how the categories of group of questions 3 of women were grouped.

Table 6

Categories grouping of women questions group 3

\begin{tabular}{|c|c|c|}
\hline Group & $\begin{array}{l}\text { Question } \\
\text { (Categorie) }\end{array}$ & Analysis \\
\hline \multirow[t]{2}{*}{1} & P14 (Yes) & \multirow{2}{*}{$\begin{array}{l}\text { There is a correlation between women who consider it is important to make public the public } \\
\text { policy of religious freedom and the public policy of fundamental freedoms of religion and } \\
\text { conscience to the citizens of Bogotá with the advancement of programs for the prevention of } \\
\text { domestic violence due to religious violence in their locality. }\end{array}$} \\
\hline & P15 (Yes) & \\
\hline
\end{tabular}

Source: Autors

A group of women who consider it important that becomes known public policy of religious freedom and public policy fundamental freedoms of religion and conscience was evident to the people in Bogotá, Colombia, which 
also agree on which programs are ahead for the prevention of domestic violence due to religious violence in your locality.

Analysis of Group 4 (P5, P6, P10, P13), Table 7 shows the questions and their respective categories.

Table 7

Questions

Group 4 Women

\begin{tabular}{|l|l|}
\hline QUESTION & CATEGORIES \\
\hline $\begin{array}{l}\text { P5. Did you know that there is a fundamental right to religious freedom and a public policy } \\
\text { of fundamental freedoms of religion and conscience? }\end{array}$ & Yes; No \\
\hline $\begin{array}{l}\text { P6. Do you accept that in your family, some of your members choose to practice a religion } \\
\text { different from yours? }\end{array}$ & Yes; No \\
\hline $\begin{array}{l}\text { P10. ¿ं If in your family is presenting acts of violence by religious freedom of religion and } \\
\text { conscience, would request a protective measure? }\end{array}$ & Yes; No \\
\hline $\begin{array}{l}\text { P13. Do you consider important that domestic violence be punished for religious freedom } \\
\text { in Bogotá? }\end{array}$ & Always; sometimes; never. \\
\hline
\end{tabular}

Source: Autors

Figure 6 shows the result of correspondence analysis of Group 4 of women questions.

Figure 6

Result Correspondence Analysis

of women questions Group 4

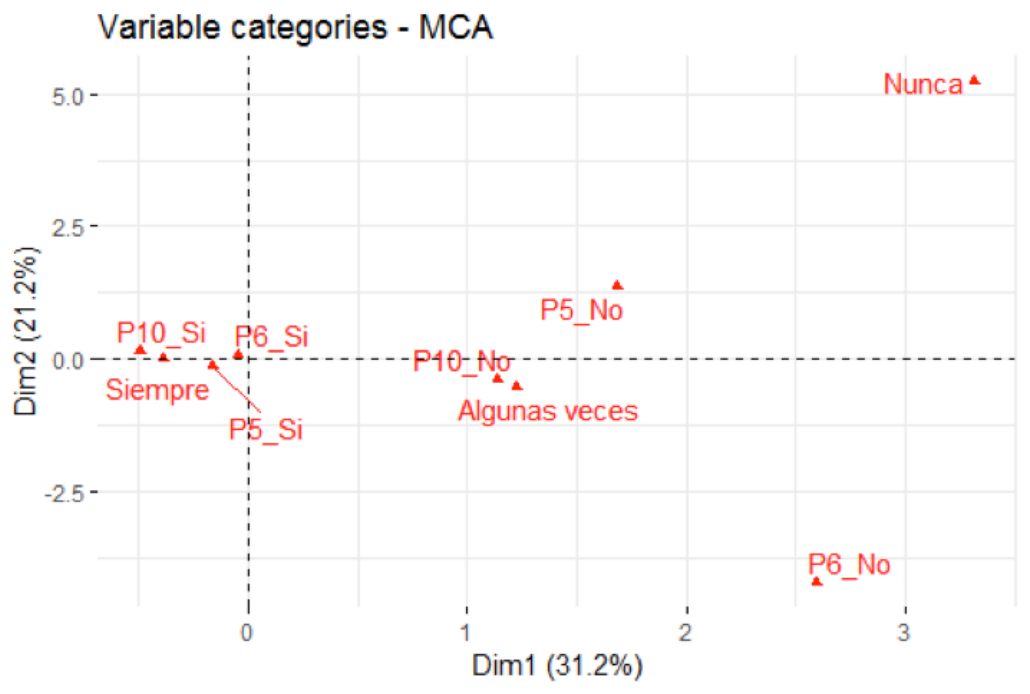

Source: Software R., Adapted Autors

Table 8 shows how the categories of group of questions 4 of women were grouped. 
Table 8

Categories grouping of women

questions group 4

\begin{tabular}{|c|c|c|}
\hline Group & $\begin{array}{l}\text { Question } \\
\text { (Categorie) }\end{array}$ & Analysis \\
\hline \multirow[t]{4}{*}{1} & P5 (Yes) & \multirow{4}{*}{$\begin{array}{l}\text { There is a correlation with the group of women who know there is a fundamental right to } \\
\text { religious freedom and a public policy of fundamental freedoms of religion and conscience, with } \\
\text { which they accept that in their family, some of their members choose to practice a religion } \\
\text { different from their own and they would request protection measures in the event that some } \\
\text { acts of violence for religious freedom, worship and conscience occur in the family, and } \\
\text { additionally consider that intra-family violence for religious freedom be sanctioned in Bogotá. }\end{array}$} \\
\hline & P6 (Yes) & \\
\hline & P10 (Yes) & \\
\hline & P13 (Always) & \\
\hline \multirow[t]{3}{*}{2} & P5 (No) & \multirow{3}{*}{$\begin{array}{l}\text { There is a correlation between women who do not know that there is a fundamental right to } \\
\text { religious freedom and the public policy of fundamental freedoms of religion and conscience, } \\
\text { with whom they would not request protection measures in the event of violence occurring in } \\
\text { the family for religious freedom, worship and conscience and consider that sometimes } \\
\text { domestic violence for religious freedom should be sanctioned in Bogotá. }\end{array}$} \\
\hline & P10 (No) & \\
\hline & $\begin{array}{l}\text { P13 } \\
\text { (Sometimes) }\end{array}$ & \\
\hline
\end{tabular}

Source: Autors

In summary, two groups of women can be defined. The first group, corresponds to women who know that there is a fundamental right to religious freedom, which would also accept that a member of the family to practice different religion to them and agree to punish intra-familial violence for religious freedom and therefore they are consistent in requesting protection in the event of religious violence occurring in the family. Instead, the second group of women, is made up of who do not know that there is a fundamental right to religious freedom, and additionally consider it not important punish violence by religious freedom nor would apply protective measures in the event that present in the family some act of violence for religious freedom.

4.2. Men's group. The first analysis corresponds to determining between which questions there is a correspondence between the group of men in order to group them among themselves for the analysis. The result is seen in Figure 7.

Figure 7

Result Correspondence Analysis of questions within the group of men

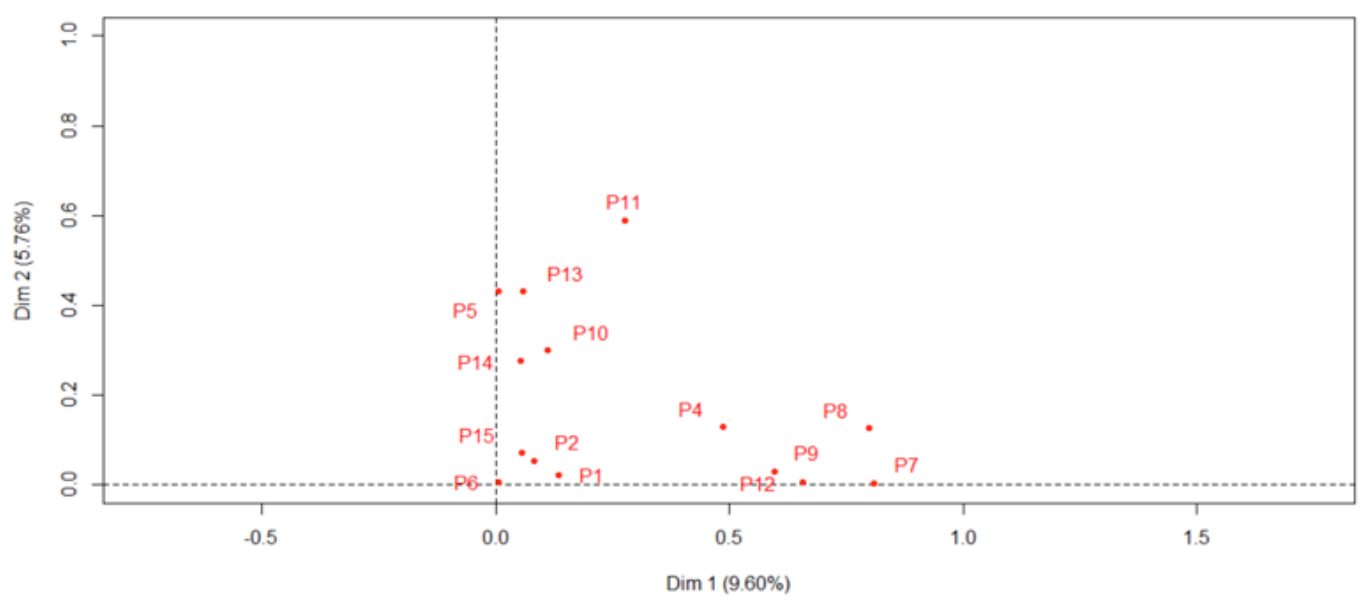

Source: Software R., Adapted Autors

Based on the results, it was determined to group the questions as follows:

- Group 1 (P5, P10, P13, P14) 
- $\quad$ Group 2 (P1, P2, P6, P15)

- $\quad$ Group 3 (P4, P7, P8, P9, P12)

Analysis of Group 1 (P5, P10, P13, P14), Table 9 shows the questions and their respective categories.

Table 9

Questions Group 1 Men

\begin{tabular}{|l|l|}
\hline QUESTION & CATEGORÍES \\
\hline $\begin{array}{l}\text { P5. Did you know that there is a fundamental right to religious freedom and a public policy of } \\
\text { fundamental freedoms of religion and conscience? }\end{array}$ & Yes; No \\
\hline $\begin{array}{l}\text { P10. If there were acts of violence in your family for religious freedom, worship and conscience, } \\
\text { would you request a protection measure? }\end{array}$ & Yes; No \\
\hline $\begin{array}{l}\text { P13. Do you consider it is important that domestic violence be punished for religious freedom in } \\
\text { Bogotá? }\end{array}$ & $\begin{array}{l}\text { Always; } \\
\text { sometimes; never. }\end{array}$ \\
\hline $\begin{array}{l}\text { P14. Do you think it is important that the public policy of religious freedom and the public policy of } \\
\text { fundamental freedoms of religion and conscience be made known to the people of Bogotá? }\end{array}$ & Yes; No \\
\hline
\end{tabular}

Source: Autors

Figure 8 shows the result of correspondence analysis of Group 1 of men questions.

Figure 8

Result Correspondence Analysis

of men questions Group 1.
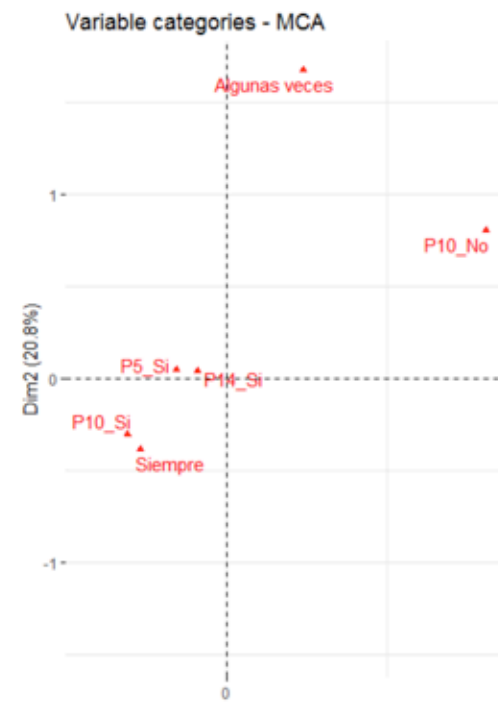

No
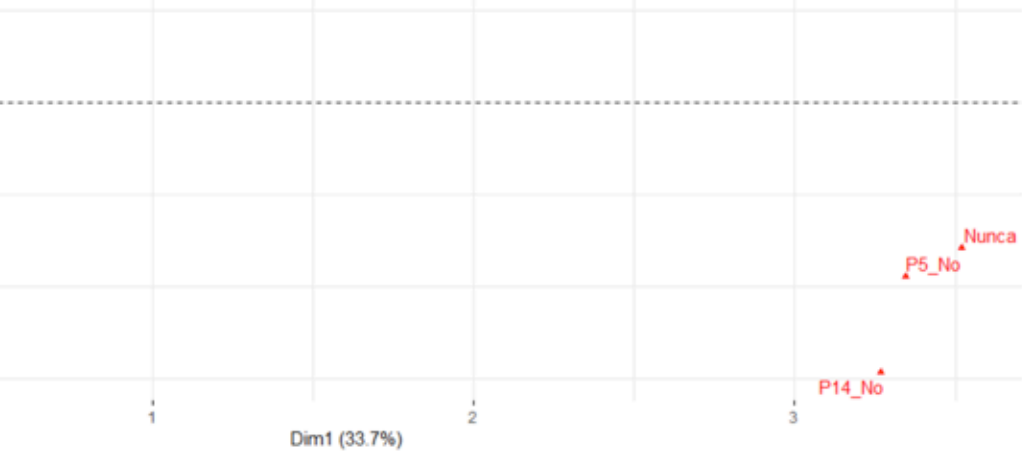

Source: Software R., Adapted Autors

Table 10 shows how the categories of group of men questions 2 were grouped. 
Table 10

Questions group 2 men.

\begin{tabular}{|c|c|c|}
\hline Group & $\begin{array}{l}\text { Question } \\
\text { (Categorie) }\end{array}$ & Analysis \\
\hline \multirow[t]{4}{*}{1} & P5 (Yes) & \multirow{4}{*}{$\begin{array}{l}\text { There is a correlation with the group of men who know there is a fundamental right to religious } \\
\text { freedom and the public policy of fundamental freedoms of religion and conscience, they would } \\
\text { also request protection measures in the event of any acts of violence for religious freedom of } \\
\text { worship and conscience occurring in the family, and additionally consider that it is important to } \\
\text { sanction domestic violence for religious freedom in Bogotá; and finally they consider that it is } \\
\text { important to publicize the public policy of religious freedom and the public policy of } \\
\text { fundamental freedoms of religion and conscience. }\end{array}$} \\
\hline & P10 (Yes) & \\
\hline & P13 (Always) & \\
\hline & P14 (Yes) & \\
\hline \multirow[t]{3}{*}{2} & P5 (No) & \multirow{3}{*}{$\begin{array}{l}\text { There is a correlation between men who do not know that there is a fundamental right to } \\
\text { religious freedom and the public policy of fundamental freedoms of religion and conscience, } \\
\text { with those who consider that domestic violence for religious freedom should not be sanctioned } \\
\text { in Bogotá and consequently neither they consider that the public policy of religious freedom and } \\
\text { the public policy of fundamental freedoms of religion and conscience should be made known. }\end{array}$} \\
\hline & P13 (Never) & \\
\hline & P14 (No) & \\
\hline
\end{tabular}

Source: Autors

In conclusion, two groups can be determined, the first is the group of men who, if they know the existence of the fundamental right to religious freedom and the public policy of fundamental freedoms of religion and conscience, also consider it is important to sanction laws in this regard, and are consequent to also agree with the importance of publicizing or knowing these laws. On the other hand, the second group is that of men who do not know the existence of this fundamental right and do not see it necessary to sanction laws of this type and therefore, much less make known laws of this type.

Analysis of Group 2 (P1, P2, P6, P15), Table 11 shows the questions and their respective categories.

Table 11

Questions Group 2 men.

\begin{tabular}{|l|l|}
\hline QUESTION & CATEGORÍES \\
\hline P1. Do you and your family belong to a certain religion? & Yes; No \\
\hline P2. Do you consider that religion contributes values in the family to prevent domestic violence? & Yes; No \\
\hline $\begin{array}{l}\text { P6. Do you accept that in your family, some of your members choose to practice a religion different from } \\
\text { yours? }\end{array}$ & Yes; No \\
\hline $\begin{array}{l}\text { P15. Do you agree with the prevention of domestic violence preclusion programs for religious violence } \\
\text { in your locality? }\end{array}$ & Ye; No \\
\hline
\end{tabular}

Source: Autors

In Figure 9, the result of correspondence analysis of the Group 2 questions men is observed. 
Figure 9

Result Correspondence Analysis

of men questions Group 2

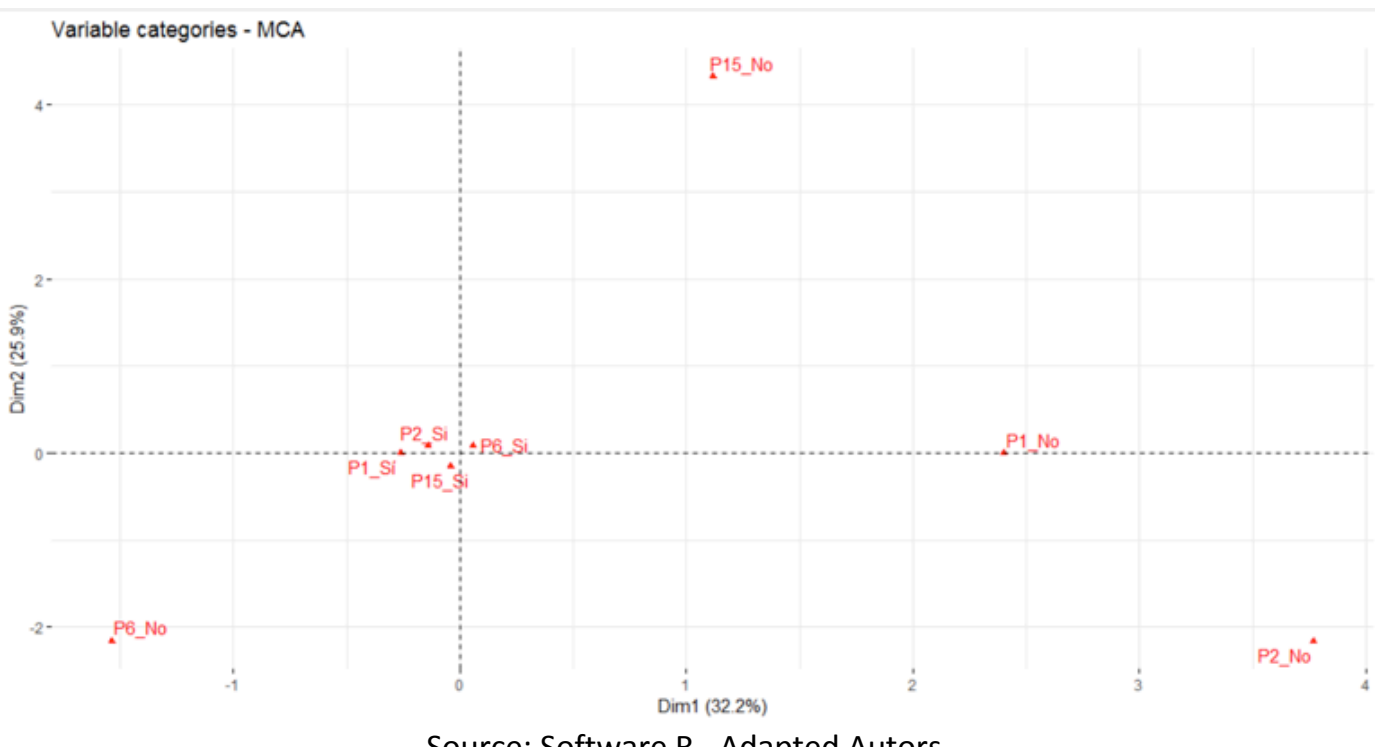

Source: Software R., Adapted Autors

Table 12 shows how the categories of the questions 2 of men group were grouped.

Table 12

Categories Grouping of men questions group 2.

\begin{tabular}{|c|c|c|}
\hline Group & $\begin{array}{l}\text { Question } \\
\text { (Categorie) }\end{array}$ & Analysis \\
\hline \multirow[t]{4}{*}{1} & P1 (Yes) & \multirow{4}{*}{$\begin{array}{l}\text { There is a correlation between a group of men who, if they practice any religion and } \\
\text { consider that religion contributes values in the family to prevent domestic violence, would } \\
\text { also accept that a member of their family practiced a religion different from theirs, and } \\
\text { they agree that programs for the prevention of domestic violence due to religious violence } \\
\text { be carried out in your locality. }\end{array}$} \\
\hline & P2 (Yes) & \\
\hline & P6 (Yes) & \\
\hline & P15 (Yes) & \\
\hline \multirow[t]{2}{*}{2} & P1 (No) & \multirow{2}{*}{$\begin{array}{l}\text { There is a correlation between a group of men who do not practice any religion and do } \\
\text { not consider that religion contributes values in the family to prevent domestic violence. }\end{array}$} \\
\hline & P2 (No) & \\
\hline
\end{tabular}

Source: Autors

In summary, they can be grouped into two groups of men, who are men who practice a religion and consider that religion contributes values in the family to prevent domestic violence, would accept that a member of their family practices another religion and are also agree that programs for the prevention of domestic violence due to religious violence are carried out, and the other group are those who do not practice a religion and consider that religion does not contribute values in the family to prevent domestic violence.

Analysis of Group 3 (P4, P7, P8, P9, P12), Table 13 shows the questions and their respective categories.

Table 13

Questions Group 3 men.

\begin{tabular}{|l|l|}
\hline Question & Categoríes \\
\hline $\begin{array}{l}\text { P4. How often do you attend the place where you practice your } \\
\text { religious beliefs? }\end{array}$ & $\begin{array}{l}\text { Every day; } 1 \text { or } 2 \text { times a week; Weekends; Once a } \\
\text { month; Every six months; Once a year; On special } \\
\text { dates; never }\end{array}$ \\
\hline $\begin{array}{l}\text { P7. During the years from } 2014 \text { to 2018, have you been a victim } \\
\text { of violence because of the religion that you practice in your } \\
\text { family? }\end{array}$ & Yes; No \\
\hline
\end{tabular}




\begin{tabular}{|l|l|}
\hline Question & Categoríes \\
\hline $\begin{array}{l}\text { P8. If you have suffered intra-family violence due to a different } \\
\text { religion, cult or belief with your family, the violence has been: }\end{array}$ & Verbal; physical; psychological; economic. \\
\hline $\begin{array}{l}\text { P9. If you have been a victim of domestic violence because of the } \\
\text { religion you practice, did you report these facts? }\end{array}$ & $\begin{array}{l}\text { Yes; No; I have not been a victim of this domestic } \\
\text { violence. }\end{array}$ \\
\hline $\begin{array}{l}\text { P12. ¿ Do you know of other cases of people who have been } \\
\text { victims of domestic violence due to religion during the years 2014 } \\
\text { to } 2018 \text { in the Bogotá city? }\end{array}$ & Yes; No \\
\hline
\end{tabular}

Source: Autors

Figure 10 shows the result of correspondence analysis for Group 3 of men questions.

Figure 10

Result Correspondence Analysis of men questions Group 3.

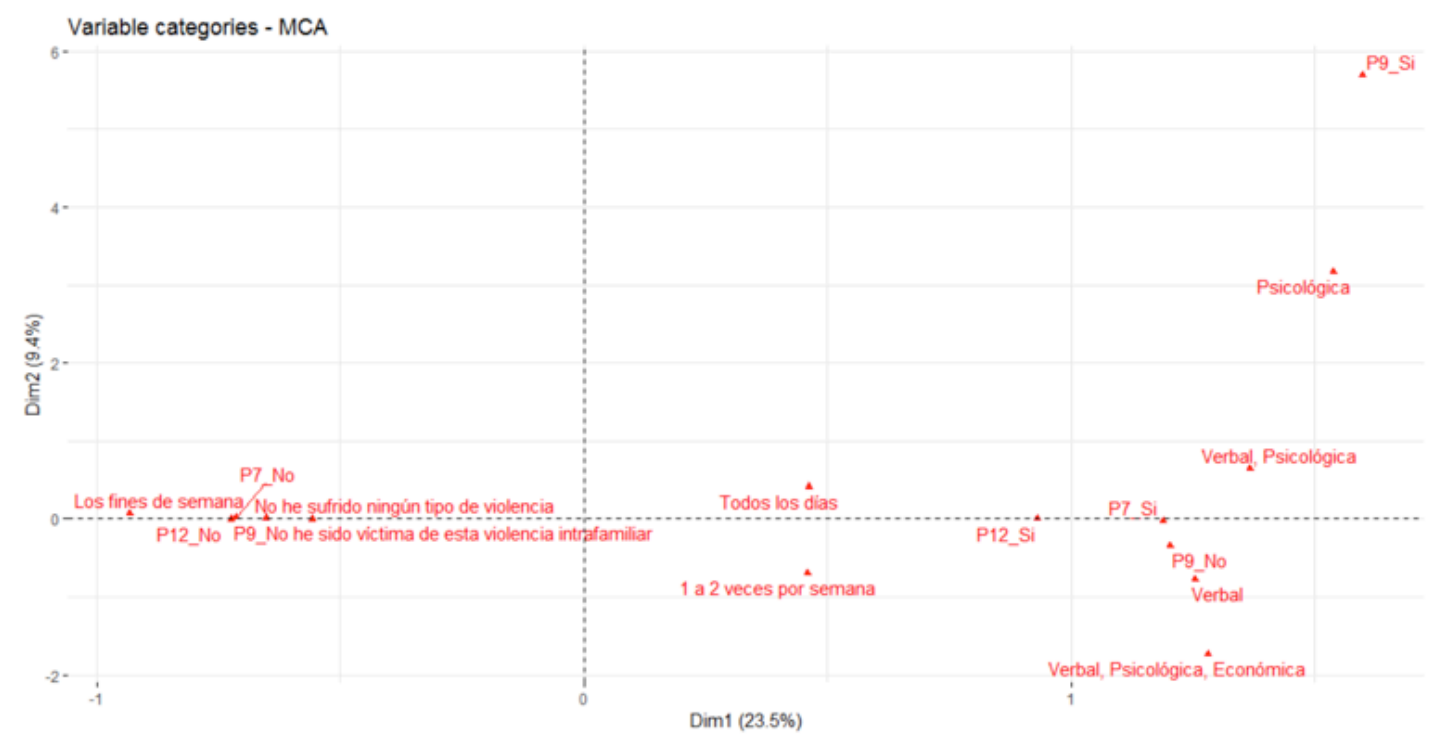

Source: Software R., Adapted Autors

Table 14 shows how the categories of group of questions 3 of men were grouped.

Table 14

Categories Grouping of men questions group 3

\begin{tabular}{|c|c|c|}
\hline Group & Question (Categorie) & Analysis \\
\hline \multirow[t]{4}{*}{1} & P4 (weekends) & \multirow{4}{*}{$\begin{array}{l}\text { There is a correlation between the group of men who go only on weekends to carry out } \\
\text { their religious practice, and have not suffered any type of religious violence, or intra- } \\
\text { family violence and do not know of other cases. }\end{array}$} \\
\hline & P7 (No) & \\
\hline & $\begin{array}{l}\text { P9 ( I have not been a } \\
\text { victim of this domestic } \\
\text { violence) }\end{array}$ & \\
\hline & P12 (No) & \\
\hline \multirow[t]{4}{*}{2} & P7 (Yes) & \multirow{4}{*}{$\begin{array}{l}\text { There is a correlation between the group of men who have suffered violence due to } \\
\text { their religion, which have suffered verbal, psychological or economic violence, but they } \\
\text { did not report this fact and they also know of other cases of religious violence. }\end{array}$} \\
\hline & P8 (Verbal) & \\
\hline & P8 (Verbal, Psicologic) & \\
\hline & $\begin{array}{l}\text { P8 (Verbal, Psicologic, } \\
\text { Economic) }\end{array}$ & \\
\hline
\end{tabular}

Source: Autors 
Two groups of men are evidenced, the first, those who have not suffered religious violence and do not know of other cases, and the second group that have suffered religious violence, for example verbal, psychological or economic, but did not report what happened and know other similar cases.

The following section compares the results obtained between men and women.

\section{Comparison of religious violence between men and women}

From the results found, a comparative table will be made between what was found in the group of men and women respondents (See Table 15).

Table 15

Results Comparison

\begin{tabular}{|c|c|c|}
\hline WOMEN & MEN & COMPARISON \\
\hline $\begin{array}{l}\text { Group } 1 \text {. Women who have not suffered } \\
\text { religious violence. } \\
\text { Group } 2 \text {. Women who have suffered violence } \\
\text { due to their religious practice and the type of } \\
\text { violence they have suffered are verbal and } \\
\text { psychological, and although they suffered this } \\
\text { type of violence, they did not report these } \\
\text { events. }\end{array}$ & $\begin{array}{l}\text { Group 1. Men who have not suffered religious } \\
\text { violence and do not know of other cases. } \\
\text { AND } \\
\text { Group 2. Men who have suffered religious } \\
\text { violence, for example verbal, psychological or } \\
\text { economic, but did not report what happened and } \\
\text { know of other similar cases. }\end{array}$ & $\begin{array}{l}\text { Similarities. Both in men and women it is } \\
\text { evident that there is a group that has not } \\
\text { suffered religious violence and those that did } \\
\text { suffer did not report the fact and the type of } \\
\text { verbal or psychological violence. } \\
\text { Differences. The only perceived difference is } \\
\text { that men also experience economic violence. }\end{array}$ \\
\hline $\begin{array}{l}\text { Group } 1 \text {. Women who practice a religion and } \\
\text { consider that religion contributes values in } \\
\text { the family to prevent domestic violence. } \\
\text { Group } 2 \text {. Women who do not practice a } \\
\text { religion and consider that religion does } \\
\text { not contribute values in the family to prevent } \\
\text { domestic violence. }\end{array}$ & $\begin{array}{l}\text { Group 1. Men who practice a religion and consider } \\
\text { that religion contributes values in the family to } \\
\text { prevent domestic violence, would accept that a } \\
\text { member of their family practices another religion } \\
\text { and also agree that programs for the prevention of } \\
\text { domestic violence due to religious violence be } \\
\text { carried out. } \\
\text { Group } 2 \text {. Men who do not practice a religion and } \\
\text { consider that religion does not contribute values } \\
\text { in the family to prevent domestic violence. }\end{array}$ & $\begin{array}{l}\text { Similarities. So men and women clearly } \\
\text { determine two (2) groups. Those who practice a } \\
\text { religion believe that religion contributes values } \\
\text { that prevent intra-family violence and those } \\
\text { who do not practice any religion believe } \\
\text { that religion does not provide values for the } \\
\text { prevention of intra-family violence. } \\
\text { Differences. The only difference is that } \\
\text { men who practice a religion and believe } \\
\text { this to securities holders also accept that a } \\
\text { member of his family to practice another } \\
\text { religion. }\end{array}$ \\
\hline $\begin{array}{l}\text { Group } 1 . \text { Women who know that there is a } \\
\text { fundamental right to religious freedom, who } \\
\text { would also accept that a member of the } \\
\text { family practices a different religion from } \\
\text { them, and agree that domestic violence for } \\
\text { religious freedom is sanctioned and therefore } \\
\text { they are consistent in requesting protection } \\
\text { in the event of religious violence occurring in } \\
\text { the family. } \\
\text { Group } 2 \text {. Women are those who do not know } \\
\text { that there is a fundamental right to religious } \\
\text { freedom, and additionally consider that it is } \\
\text { not important to punish violence for religious } \\
\text { freedom and would not request protection } \\
\text { measures in the event of any occurrence in } \\
\text { the family of violence for religious freedom. }\end{array}$ & $\begin{array}{l}\text { Group } 1 \text {. Men who, if they know the existence of } \\
\text { the fundamental right to religious freedom and } \\
\text { the public policy of fundamental freedoms of } \\
\text { religion and conscience, also consider it important } \\
\text { to sanction laws in this regard, and are consequent } \\
\text { in also agreeing with the importance of giving to or } \\
\text { know these laws. Group } 2 \text {. Men who do not know } \\
\text { about the existence of this fundamental right and } \\
\text { do not see it necessary to sanction laws of this type } \\
\text { and therefore, much less make known laws of this } \\
\text { type. }\end{array}$ & $\begin{array}{l}\text { Similarities. In men and women there are two } \\
\text { groups of those who know that there is a } \\
\text { fundamental right to religious freedom and } \\
\text { those who do not. } \\
\text { Differences Although the two groups exist } \\
\text { between men and women, the perspective } \\
\text { varies, for women they are more concerned } \\
\text { with sanctioning the behavior of religious } \\
\text { violence and there is a protection system, } \\
\text { instead it focuses more on the need to sanction } \\
\text { and enact laws. This means that the application } \\
\text { of the laws is more important for women, while } \\
\text { for men it is their existence and knowledge. }\end{array}$ \\
\hline $\begin{array}{l}\text { A group of women who consider it important } \\
\text { to make public the public policy of religious } \\
\text { freedom and the public policy of fundamental } \\
\text { freedoms of religion and conscience to the } \\
\text { citizens of Bogotá, who also agree that } \\
\text { programs for the prevention of domestic } \\
\text { violence due to violence be carried out } \\
\text { religious in your locality. }\end{array}$ & There is not & $\begin{array}{l}\text { Similarities. None, there is no group in men with } \\
\text { the perspective of women. }\end{array}$ \\
\hline
\end{tabular}

Source: Autors

In relation to violence because of their religious belief between men and women, the only difference is that men perceive that they suffer economic violence from this cause. Another difference between men and women who practice some religion and believe that religion contributes values for the prevention of domestic violence, is that the men in this group would also accept that a member of their family practices another religion, being 
consistent with what was stated. Among the group of men and women who know that there will fundamental right of religious freedom, perspective of men and women is different, in the case of women, they are more concerned with the application of the existing law and the establishment of protective measures, on the other hand, men are more concerned with the creation and enactment of these laws in the citizenry. In women, there is evidence of interest in publicizing public policies regarding religious freedom as a whole, to carry out programs for the prevention of domestic violence due to religious violence in their locality.

With respect to the points that are similar men and women, will deepen in the analysis of these, through a descriptive and inferential analysis.

\section{Descriptive and Inferential Analysis}

Based on the results obtained with the ACM, the responses to 3 survey questions will be analyzed, which are:

- P7. During the years 2014-2018, you have been victim of violence because of religion practiced in your family?

- P5. Did you know that there is a fundamental right to religious freedom and fundamental freedoms of religion and conscience public policy?

- P2. Do you consider that religion contributes values in the family to prevent domestic violence?

\section{Results Difference of proportions tests}

The $Z$ test was used to compare the proportions of two populations. To carry out the hypothesis tests, some assumptions were verified:

- The two random samples are independent of each other

- Sample size is large enough

Then, the following hypothesis test was performed

- The hypothesis test: $H_{0}: p_{1}=p_{2}$ vs. $H_{1}: p_{1} \neq p_{2}$

It worked with a significance of $\alpha=0.05$. Also, the two-dimensional contingency tables were built, one of these being Gender vs. Answer Question \#_. To then show the results of these tests for differences in proportions.

Table 16 and Figure 11 present the results of question 7.

Table 16

Genre Answer vs. question 7

\begin{tabular}{|c|c|c|c|}
\hline Question 7 & No & Yes & Grand Total \\
\hline Female & 151 & 87 & 238 \\
\hline Male & 70 & 42 & 112 \\
\hline Grand Total & 221 & 129 & 350 \\
\hline
\end{tabular}

Source: Autors 
Figure 11

Gender answer vs. question 7

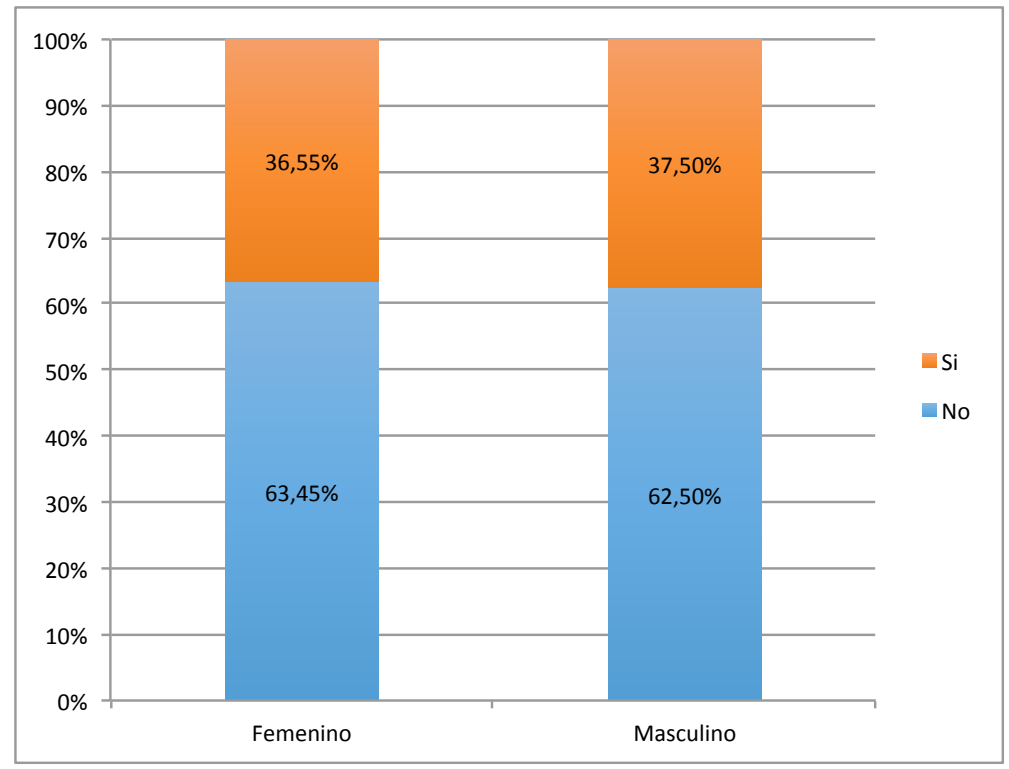

Source: Autors

When observing the results, it is hypothesized that proportionally the number of men and women who have suffered religious violence is the same. Therefore, it poses a hypothesis test to reject or accept it. Where the result is exposed in Figure 12.

Figure 12

Proportion of difference in proportions test question 7

2-sample test for equality of proportions with continuity correction

data: Tab1ac

$\mathrm{X}$-squared $=0.0027307, \mathrm{df}=1, \mathrm{p}$-value $=$

0.9583

alternative hypothesis: two.sided

95 percent confidence interval:

$\begin{array}{ll}-0.1056568 & 0.1245644\end{array}$

sample estimates:

prop 1 prop 2

0.63445380 .6250000

Source: Software R., Adapted Autors

With $95 \%$ of confidence, the null hypothesis is not rejected, there is statistical evidence that concludes that the proportion of Men who answered NO to question 7 is equal to the proportion of Women who answered NO to question 7.

Table 17 and Figure 13 present the results of question 5.

Table 17

Gender answer vs. question 5

\begin{tabular}{|c|c|c|c|}
\hline Row labels & No & Yes & Grand Total \\
\hline Female & 21 & 217 & 238 \\
\hline Male & 5 & 107 & 112 \\
\hline Grand Total & 26 & 324 & 350 \\
\hline
\end{tabular}

Source: Autors 
Figure 13

Gender answer vs. question 5

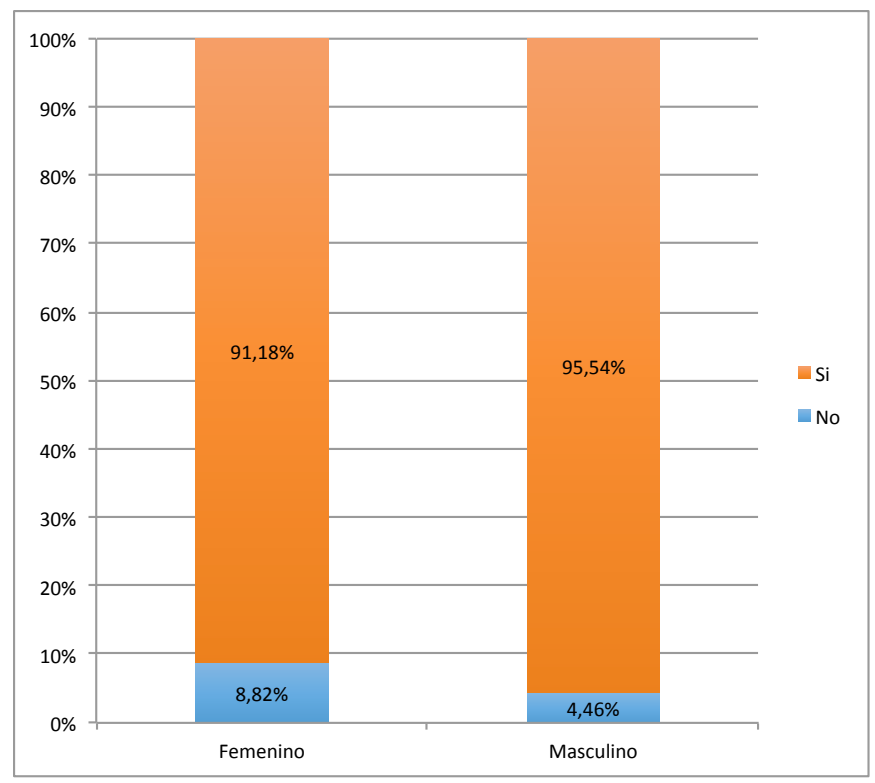

Source: Autors

When observing the results, it is hypothesized that both men and women know in the same proportion the existence of the fundamental right of religious freedom and the public policy of fundamental freedoms of religion and conscience. Therefore, a hypothesis test is proposed to reject or accept it. Where the result is observed in Figure 14.

Figure 14

Proportion of difference in proportions test question 5.

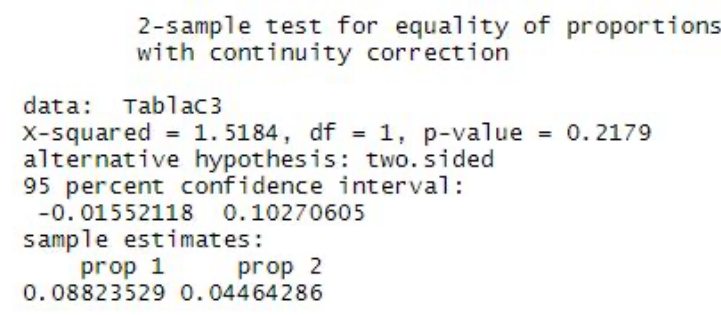

Source: Software R., Adapted Autors

With $95 \%$ of confidence the null hypothesis is not rejected, there is statistical evidence that concludes that the proportion of Men who answered NO to question 5 is equal to the proportion of Women who answered NO to question 5 .

Table 18 and Figure 15 present the results of question 2.

Table 18

Gender answer vs. question 2

\begin{tabular}{|c|c|c|c|}
\hline Question 2 & No & Yes & Grand Total \\
\hline Female & 8 & 230 & 238 \\
\hline Male & 4 & 108 & 112 \\
\hline Grand Total & 12 & 338 & 350 \\
\hline
\end{tabular}


Figure 15

Gender answer vs. question 2

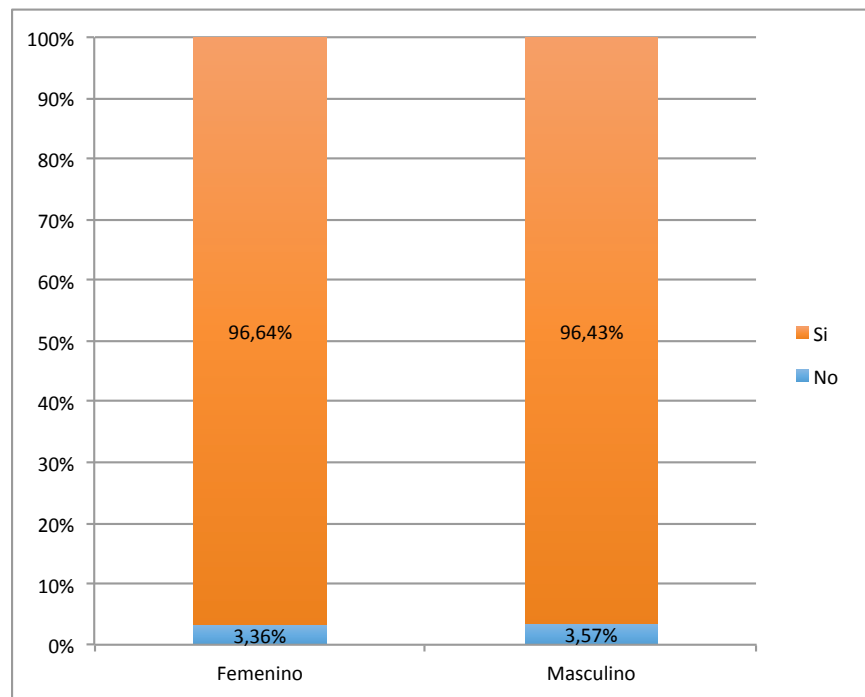

Source: Autors

When observing the results, the hypothesis that both men and women consider in the same proportion that religion contributes values in the family to prevent domestic violence is raised. Therefore, it poses a hypothesis test to reject or accept it. Where the result is found in Figure 16.

Figure 16

Proportion of difference in proportions test question 2 .

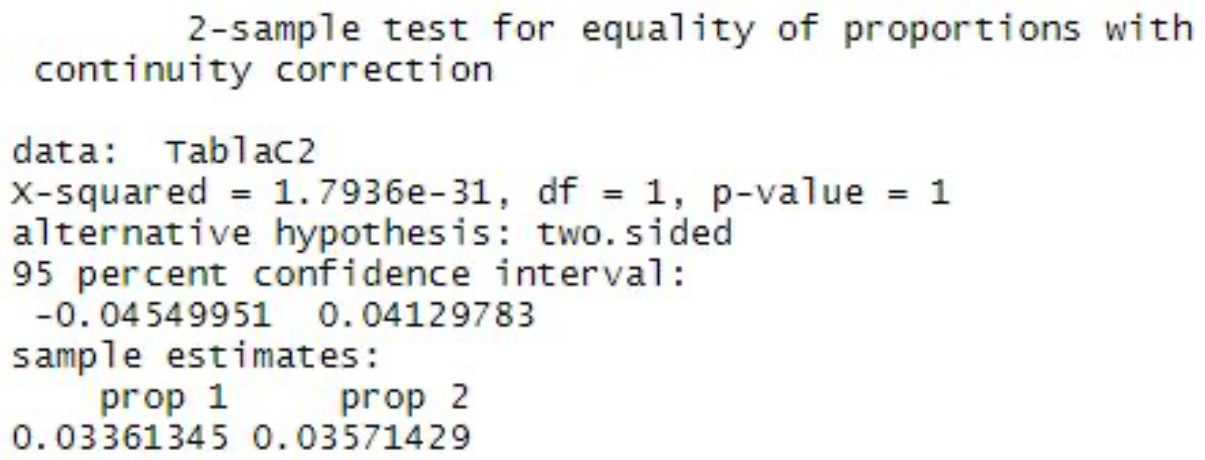

Source: Software R., Adapted Autors

With a 95\% confidence not reject the null hypothesis, no statistical evidence that concludes that the proportion of men responding NO in question 2 is equal to the ratio of women NO responding to question 2.

Based on the results obtained, it can be affirmed that there are no significant differences between men and women in the number that have suffered some type of religious violence. Also states that between men and women have the same level of knowledge in the existence of the fundamental right of religious freedom and public policy fundamental freedoms of religion and conscience. And finally, that between men and women alike believe that religion brings family values to prevent domestic violence. 


\section{Conclusions}

According to the results of statistics applied with the multiple correspondence technique, the following can be concluded:

Proportionally, the number of men and women surveyed that have suffered religious violence is the same. Where they state that they have suffered verbal and psychological violence, and the men state that they have also suffered economic violence.

Men and women who practice a religion believe that it does provide values to prevent family violence, and those who do not believe that religion does not provide values to prevent family violence. It is evident that there are no proportional differences between men and women in this matter. From the group of men who practice a religion and believe that religion brings values, they would also accept that a member of their family practiced some other religion.

Proportionally, the number of men and women who know that there will fundamental right of religious freedom is the same. But, the perspective of these groups is different between men and women. The women are more concerned with the application of existing law and protective measures in case of, and in the case of men, they are more concerned with the creation and enactment of these laws in the community.

In women it is evident that it is important for them to known public policies regarding religious freedom and jointly advance programs to prevent domestic violence by religious violence in your area.

\section{Referencias bibliográficas}

Arévalo Barea, A. R. (2016). ABUSO INFANTIL. Revista Médica La Paz , 22 (2).

Biblioteca del Congreso Nacional de Chile. (2015). Violencia sexual contra la infancia : el avance legislativo y sus desafíos. Santiago de Chile: Ediciones Biblioteca del Congreso Nacional de Chil.

Cepeda Espinoza, M. J. (2005). Sentencia C-674/05. Retrieved 26 de 05 de 2020 from Corte Constitucional: https://www.corteconstitucional.gov.co/relatoria/2005/C-674-05.htm

Congreso de Colombia. (2000). Ley 575 del 9 de febrero del 2000. Retrieved 20 de 05 de 2020 from Congreso de Colombia: http://www.secretariasenado.gov.co/senado/basedoc/ley_0575_2000.html

Congreso de Colombia. (2008). Ley 1257 del 04 de diciembre de 2008 de Colombia. Retrieved 20 de 05 de 2020 from Congreso de Colombia: http://www.secretariasenado.gov.co/senado/basedoc/ley_1257_2008.html

Herrera Rodas, C. L., Peraza Segura, C., \& Porter Aguilar, H. (2004). El abuso verbal dentro de la violencia domestica. Medicina Legal de Costa Rica , 21 (1).

Martínez Pacheco, A. (2016). La violencia. Conceptualización y elementos para su estudio. Política y cultura , 46.

Mendoza Martelo, G. E. (2016). Sentencia T.216 de 2 de junio del 2016. Retrieved 26 de 05 de 2020 from Corte Constitucional.: https://www.corteconstitucional.gov.co/relatoria/2016/t-292-16.htm

Observatorio de la Democracia. (08 de 09 de 2017). Características y actitudes de los colombianos según su religión. Retrieved 26 de 05 de 2020 from Observatorio de la Democracia:

https://obsdemocracia.org/publicaciones/noticias/caracteristicas-y-actitudes-de-los-colombianos-seg/ 
Sánchez Lara, M. (2017). Violencia económica y patrimonial: Una aproximación a través de la atención en los municipios de Riohacha, Buenaventura y el Distrito de Cartagena. Retrieved 26 de 05 de 2020 from Consejeria Presidencial para la Equidad de la Mujer: http://www.equidadmujer.gov.co/oag/Documents/Violencia-economica-patrimonial.pdf

Soriano Faura, F. J. (2015). Promoción del buen trato y prevención del maltrato en la infancia en el ámbito de la atención primaria de la salud. From Prevensión en la Infancia y Adolecencia:

http://previnfad.aepap.org/sites/default/files/2017-04/previnfad_maltrato.pdfOrdenadas

Esta obra está bajo una Licencia Creative Commons

Attribución-NoCommercial 4.0 International

\section{(cc) EY-NC}

